
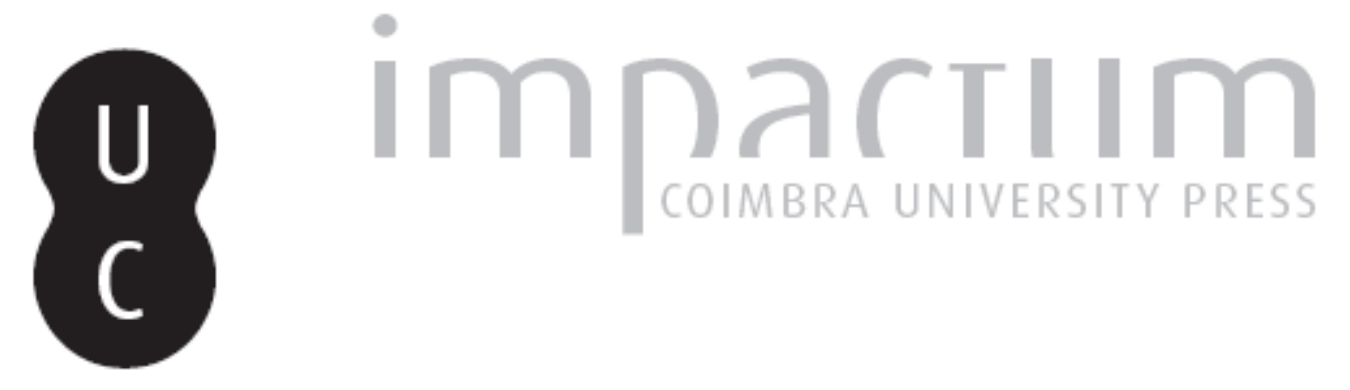

\title{
Antero de Quental nas leituras "integralistas"
}

Autor(es): $\quad$ Torgal, Luís Reis

Publicado por: Imprensa da Universidade de Coimbra

URL persistente:

URI:http://hdl.handle.net/10316.2/43754

DOI: $\quad$ DOI:https://doi.org/10.14195/2183-8925_13_17

Accessed : $\quad$ 26-Apr-2023 12:48:47

A navegação consulta e descarregamento dos títulos inseridos nas Bibliotecas Digitais UC Digitalis, UC Pombalina e UC Impactum, pressupõem a aceitação plena e sem reservas dos Termos e Condições de Uso destas Bibliotecas Digitais, disponíveis em https://digitalis.uc.pt/pt-pt/termos.

Conforme exposto nos referidos Termos e Condições de Uso, o descarregamento de títulos de acesso restrito requer uma licença válida de autorização devendo o utilizador aceder ao(s) documento(s) a partir de um endereço de IP da instituição detentora da supramencionada licença.

Ao utilizador é apenas permitido o descarregamento para uso pessoal, pelo que o emprego do(s) título(s) descarregado(s) para outro fim, designadamente comercial, carece de autorização do respetivo autor ou editor da obra.

Na medida em que todas as obras da UC Digitalis se encontram protegidas pelo Código do Direito de Autor e Direitos Conexos e demais legislação aplicável, toda a cópia, parcial ou total, deste documento, nos casos em que é legalmente admitida, deverá conter ou fazer-se acompanhar por este aviso. 
REVISTA DE HISTÓRIA DAS IDEIAS 13

\section{Antero de Quental}

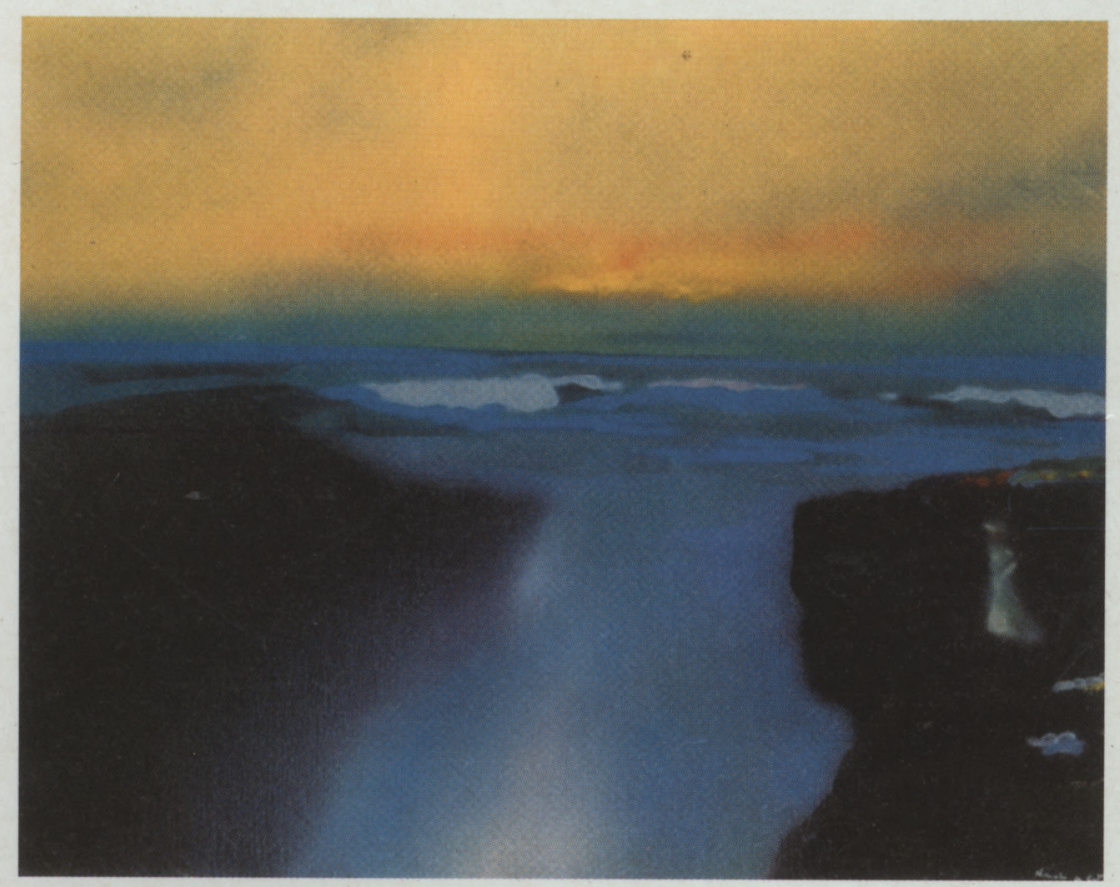

INSTITUTO DE HISTÓRIA E TEORIA DAS IDEIAS FACULDADE DE LETRAS

COIMBRA 1991 


\section{ANTERO DE QUENTAL NAS LEITURAS "INTEGRALISTAS"}

\section{História e Ideologia - as diversas leituras de Antero}

É conhecida a afirmação polémica de Benedetto Croce de que a História é sempre "contemporânea" $\left.{ }^{1}\right)$. Na verdade, sal vaguardando a ideia de que a História é uma ciência (mesmo que se considere, como dizia Le Goff, que "não é uma ciência como as outras") ( ${ }^{2}$ ), é indubitável que as relações entre a História e a Ideologia são um fenómeno incontroverso. Já o procurámos mostrar no nosso último livro $\left({ }^{3}\right)$ e, por isso, não gastaremos mais tempo para o provar e comprovar, no plano teórico e no plano prático. Diremos, no entanto, que se épocas, acontecimentos, instituições, personalidades são passíveis de várias leituras, mais diferenciadas e subtis são as interpretações produzidas acerca dos grandes vultos da cultura. Considerados como "glórias nacionais" ou "universais", são lidos e mesmo assimilados pelas diversas ideologias "à sua maneira", procurando-os transformar, cada uma delas, no seu próprio "património". E isso sucede assim, mesmo que certas ideologias não possam admitir nessas "figuras imortais" alguns aspectos da sua manifestação genial. Funciona então o argumento da "compreensão" perante determinados "erros", para valorizar sobretudo os aspectos que, querem crer e fazer crer, se adaptam a substância do seu pensamento. Claro que os discursos interpretativos

\footnotetext{
* Faculdade de Letras da Universidade de Coimbra.

(') La Storia come pensiero e come azione, ed. de 1938, p. 5.

(2) "História", in Enciclopédia. 1. Memória-História, ed. portuguesa, Einaudi-Imprensa Nacional, Lisboa, 1984, p. 158.

(') História e Ideologia, Coimbra, Minerva, 1989.
} 
nem sempre são assim lineares, porque - é evidente - o vector ideológico não é por vezes dominante. Factores científicos e culturais introduzem notas de complexidade no fenómeno da recepção. No entanto, as ideologias orientam as leituras ou pelo menos estão sempre presentes, mesmo quando parecem lá não estar.

Antero de Quental é daquelas grandes figuras da cultura portuguesa, e mesmo universal, que não poderiam preservar-se a essa diversidade interpretativa. É o que se chama uma personalidade carismática, que provoca uma verdadeira onda de empatia. Frequentemente é considerado como um dos maiores poetas portugueses - o melhor depois de Camões ou mesmo superior a Camões... Fala-se em geral da sua "actualidade" e, por isso, é passível de sobre ele se produzirem várias "leituras contemporâneas". Com isto não se pretende desvalorizar os discursos interpretativos de variadas origens e, sobretudo, a intenção e a prática científicas de alguns dos seus mais significativos intérpretes, ainda que, eles também, não estejam evidentemente fora de todo o contexto ideológico. António Salgado Júnior, Bruno Carreiro, Joaquim de Carvalho, António Sérgio, Joel Serrão, Eduardo Lourenço, Óscar Lopes, Machado Pires, Lúcio Craveiro da Silva, Ana Maria Almeida Martins, Fernando Catroga, entre outros, salientar-se-ão sempre, pese embora a saudável crítica que se possa dirigir aos seus estudos, pelo seu esforço de interpretação ou de carreamento de dados para melhor conhecer Antero.

Mas esse quadro de "leituras ideológicas" do escritor, que ficou aqui sugerido, revela-se ainda mais nítido quando se analisam alguns aspectos menos consensuais e mais polémicos da sua obra - a política, por exemplo. Salienta-se isso, mesmo quando, como hoje sucede, nos encontramos num tempo propício a "consensualidades" ou a "democraticidade" da aceitação das interpretações do "outro", ainda que, teoricamente, esse "outro" fique situado nos antípodas da ideologia do "eu".

Haja em vista o colóquio de Coimbra, efectuado em 1 e 2 de Julho de 1991, chamado sintomaticamente "Leituras de Antero". O painel "Antero e a Política" em vez de congregar estudiosos do pensamento político e da prática política de Antero de Quental, juntou antes - sem dúvida intencionalmente - personalidades de vários sectores ideológicos, que procurariam, assim se desejava, interpretar Antero "a seu 
modo". Os nomes de Adriano Moreira, António Reis, Fernando Piteira Santos, Francisco Louçã, Guilherme de Oliveira Martins, Vital Moreira e Víctor de Sá (para além de Romero Magalhães, que coordenou a mesa) não deixam grande margem para duvidar desta interpretação relativamente a uma intencionalidade que não queremos discutir mas sim constatar. No fundo o que - segundo cremos - parece ter estado presente na ideia dos organizadores do encontro é que Antero de Quental possui uma "actualidade política" que conduz a várias "contemporaneidades interpretativas". E isto mesmo que se tenha verificado um louvável esforço de objectividade analítica dos participantes (alguns deles estudiosos de Antero) e ainda que, intencionalmente também, os organizadores tenham feito preceder esse painel de uma conferência proferida por um anterianista, Fernando Catroga, que falou de "Metafísica e Política em Antero".

A "releitura de algumas leituras" de Antero de Quental já foi abordada por Fernando Catroga num dos seus mais conhecidos artigos $\left({ }^{4}\right)$. Ali analisou as leituras de Joaquim de Carvalho, de António Sérgio e a leitura integralista. Portanto, o que nos propomos aqui explorar está na linha de continuação de um trabalho desse investigador. Mas também está na sequência de uma série de análises "práticas" que temos vindo a realizar, nas quais contemplámos sobretudo as leituras "integralistas" de épocas, acontecimentos e personalidades da história.

Importa, porém, antes de iniciarmos esse estudo, de nos interrogarmos sobre o sentido, propositadamente abrangente, até por comodidade discursiva, do termo "integralismo", que utilizamos. É que se trata, evidentemente, de um conceito equívoco e de emprego discutível.

Quando se fala de "integralismo", ocorre ao politólogo e ao historiador da política o movimento concreto do "Integralismo Lusitano", defensor de uma monarquia forte ("concentradora"), mas descentralizada, orgânica, antiliberal e antidemocrática, corporativa e municipalista, católica e nacionalista. Embora radicado na ideologia tradicionalista econtra-revolucionária do século XIX, de tipo miguelino, forma-se com o grupo da Nação Portuguesa, de 1914, que um ano antes se tinha reunido na Bélgica, exilado da República Portuguesa

(4) "O problema político em Antero de Quental. Um confronto com Oliveira Martins", Revista de História das Ideias, vol. 3, pp. 341-520. 
após as incursões monárquicas de Paiva Couceiro. Neste estudo, porém, o termo "integralismo" ultrapassa este sentido específico. $\mathrm{Na}$ verdade, há elementos comuns em várias doutrinas de "direita" que povoam o nosso espaço ideológico do século XX. Por isso essas correntes, ou os elementos que as assumiram, se cruzaram ou mesmo se confundiram na mesma área ou em área idêntica. $\mathrm{O}$ depois nacional-sindicalista Rolão Preto pertenceu ao grupo dos primeiros integralistas, Salazar e os salazaristas têm ligações com o pensamento de tipo integralista, embora se radicassem também na ideologia católica social na sua versão integrista, de que os próprios integralistas também comungaram, enquanto os "católicos", como Cerejeira, conviveram neste espaço amplo com os integralistas e os futuros salazaristas e nacionais-sindicalistas.

É certo que estes grupos se individualizaram e até em certos casos vieram a colidir, mas também é verdade que, até certo ponto e até dada altura, comungaram do mesmo património ideológico ou de ideias sensivelmente comuns. Por isso pareceu-nos que nenhum termo como "integralismo" era melhor, para empregar num sentido abrangente, até porque as ideias de tradicionalismo, de corporativismo, de nacionalismo, de catolicismo... "integrais"- opostas às correntes da "modernidade" e do "progresso" liberais e republicanas - constituem elementos basilares destas linhas de pensamento e acção.

\section{Antero "mestre da Contra-Revolução" - a leitura do Integralismo} Lusitano e do Nacional-Sindicalismo

"Como Proudhon, Antero de Quental é um mestre da contrarevolução..." Estas palavras incisivas e polémicas pertencem a um integralista da primeira hora, Luís de Almeida Braga, que chama também ao poeta social "um descarado reaccionário!". Publicava-as ele em 1942, ano do centenário do nascimento do escritor, tomando posição contra um grupo de republicanos do Porto que crismara o seu recém-inaugurado centro de "Grupo republicano e recreativo Antero de Quental" (5).

Trata-se, obviamente, de uma feroz crítica ao "republicanismo",

(5) Cfr. Sob o Pendão Real, Lisboa, Edições Gama, 1942, pp. 133-145. 
inserida ainda, já um pouco a desoras, na velha polémica entre "republicanos" e "integralistas". O que se pretendia provar é que Antero nunca fora republicano e, se defendera uma "revolução", tratava-se sim de uma "revolução moral". Como Proudhon, fora um "duro inimigo das ideias e dos sentimentos que deram alma e corpo a Revolução francesa". Enfim, quando "liberto dos encantamentos de Michelet", Antero salientou-se como um autêntico "contra-revolucionário".

Mas este discurso, simples e simplisticamente polémico, de Luís de Almeida Braga, tinha raízes mais profundas e foi servido por uma argumentação de maior espessura no seio da família integralista.

$\mathrm{O}$ anti-individualismo e o antiparlamentarismo de Antero foram um facto indubitável, ainda que seja também indiscutível a diferença de perspectivas do pensamento do escritor em relação às ideologias tradicionalistas e contra-revolucionárias $\left(^{6}\right)$. No entanto, aqueles aspectos do seu pensamento, bem como a riqueza moral e mística do poeta - sintetizada apaixonadamente no "Santo Antero", do texto do seu amigo Eça de Queirós para o In Memoriam ( ) - desenquadrados da complexidade da sua personalidade e da sua obra, chegaram para que fosse apresentado como precursor da Contra-Revolução.

Foi esta, aliás, uma das estratégias mais importantes dos ideólogos integralistas. Para eles, os seus "mestres" não foram apenas os tradicionalistas antiliberais do século XIX, tais como o Marquês de Penalva, José Agostinho de Macedo, José Acúrcio das Neves, Frei Fortunato de São Boaventura, José da Gama e Castro ou Ribeiro Saraiva. Também foram apresentados como seus precursores conhecidos liberais e até republicanos e socialistas. Para isso isolaram momentos conjunturais da sua consciência político-social ou aspectos pontuais do seu ideário. Sãoexemplo disso alguns artigos e testemunhos insertos nos primeiros números da Nação Portuguesa: "O 'liberalismo' de Alexandre Herculano", "O testamento de Garrett", "Pensamento político de Eça de Queirós", "Teófilo Braga mestre da Contra-Revolução"... $\left(^{8}\right)$.

$\left(^{6}\right)$ Cfr. F. Catroga, art. cit., p. 480 ss.

( ${ }^{7}$ Antero de Quental. In Memoriam, Porto, Mathieu Lugan, 1896, p. 481 ss.

${ }^{(8)}$ Vide Nação Portuguesa, n. ${ }^{*}$ 1, 4, 10, 11, 12. 
Mas, afinal de contas, a estratégia integralista não era também original, pois seguia de perto idêntico processo utilizado em França pelos neo-tradicionalistas. Paul Bourget, que estudara o pessimismo, encontra em princípios proclamados por Balzac, Le Play ou Taine, os motivos do regresso às fontes religiosas e políticas da Contra-Revolução. Jacques Bainville apresenta Proudhon como defensor dos direitos pontifícios. Em Louis Dimier, que escreveu Les Maîtres de la Contre-Révolution, o nome de Proudhon e Balzac encontram-se entre os mentores da tradição.

Estes autores franceses são, de resto, invocados exemplarmente por António Sardinha, quando procura, também ele, apresentar Garrett e Herculano, Oliveira Martinse Ramalho Ortigão, e... Antero de Quental, como precursores da Contra-Revolução. O texto é de 1918, intitula-se, sintomaticamente, "O verdadeiro Antero" e foi publicado em 1924 na sua obra fundamental Ao Princípio era o Verbo. Em livro póstumo, AoRitmo daAmpulheta, de 1925, surgia um outroescrito complementar sobre o poeta, "A dor de Antero" ( $\left.{ }^{9}\right)$.

A tese fundamental de Sardinha é que Antero de Quental fora um intelectual torturado perante a crise do século. No entanto, o seu pessimismo não era para ele um fim mas um meio. A superação dessa crise era a sua grande finalidade. Mas não optava para a alcançar pelas crenças cientistas e demo-liberais. Ao invés, fora um precursor do intuicionismo e aspirava antes a uma redenção idealista - "O ideal colectivo, desejado por Antero, era o ideal messiânico do seu ingénuo humanitarismo", escrevia Sardinha $\left({ }^{10}\right)$. A sua "Revolução" era assim uma revolução moral, a libertação pela "santidade". Daí que a "Esperança" o acompanhasse ao longo de toda a sua vida e até na sua morte.

Antero era, pois, o homem convertido, que regressara ao Passado da sua existência. A famosa "Carta autobiográfica" a Wilhelm Storck era invocada por Sardinha, como o será constante e invariavelmente por todos os "integralistas" - ali Antero confessava ter sido "arrancado do viver quase patriarcal de uma província remota e imersa no seu plácido

(9) Consultámos Ao Princípio erao Verbo, 2." ed., Lisboa, Ed. Gama, 1940 (1." ed. 1924),"O verdadeiro Antero", pp.91-121, e Ao ritmo daAmpulheta. Crítica edoutrina. (Obra póstuma), Lisboa, Lumen, 1925, "A dôr de Antero", pp. 187-205.

$\left.{ }^{10}\right)$ Ao Princípio era o Verbo, 2." ed., p. 93. 


\section{Antero de Quental nas leituras "integralistas"}

sono histórico, por meio da irrespeitosa agitação intelectual de um centro, onde mais ou menos vinham repercutir-se as desencontradas correntes do espírito moderno" $\left({ }^{11}\right)$. A falta de "direcção" - segundo Sardinha - afastou Antero de Quental da tradição, mas a ela voltará em estado de desespero. Como Ramalho e Oliveira Martins, ele é também um "convertido". Daí que, como Proudhon e como o fará Maurras, tenha defendido o Syllabus, de Pio IX, contra o liberalismo, se tenha batido por uma "democracia orgânica" contra a decomposição da sociedade em partidos, tenha optado por um socialismo de base comunitarista e sindicalista. Antiparlamentarista e anti-individualista, Antero não se preocupava com o problema de "regime", mas defendia sim uma "revolução nacional".

Claro que em Antero também houve "erros funestos", "estouvanices da mocidade" $\left({ }^{12}\right)$ - aliás Sardinha, que fora também um "convertido", revia-se nessa experiência dramática do poeta - mas, acima de tudo e no fim de tudo, houve nele um desejo de os ultrapassar e de regressar à tradição. "Se de certo modo - escrevia Sardinha Antero adivinha a renascença espiritualista que hoje encontra no regaço da Igreja a sua expressão consciente, também para o nosso nacionalismo apaixonado Antero, como político, representa uma lição que é preciso termos sempre presente" $\left({ }^{13}\right)$. Antero era assim considerado, através deste processo interpretativo de assimilação e de transformação de "meias verdades", como um dos "camaradas mais velhos" do Integralismo. $\mathrm{Na}$ busca constante dos seus antepassados, que eram também considerados como símbolos do nacionalismo e da "universalidade portuguesa", os neo-tradicionalistas acrescentavam à lista o nome de Antero de Quental. São de Sardinha estas palavras fundamentais: "Camões na Renascença, o Padre António Vieira em Seiscentos, José Agostinho de Macedo na agonia da sociedade antiga, são a representação universal do nosso génio na Epopeia, na Política e no Panfleto. Juntemos-lhe agora Antero na Filosofia" $\left({ }^{14}\right)$.

(11) Cit. in Ao Princípio era o Verbo, p. 97. 0 "centro" a que Antero se referia era, evidentemente, Coimbra, para onde fora prosseguir os seus estudos.

(12) Cfr. ob. cit., pp. 94-95.

(13) Idem, pp. 108-109.

(14) Ao Ritmo da Ampulheta, p. 195 
Mas este entendimento de Antero de Quental como "património da Tradição" talvez não tenha sido divisado em primeira versão pelo Integralismo Lusitano e exemplarmente, como o foi, por António Sardinha. Há notórios indícios que Afonso Lopes Vieira o teria feito antes, embora de forma fundamentalmente sentimental e "literária", sem ainda entender a Tradição em toda a sua força político-social, orientação que de resto nunca foi a marca característica da sua personalidade essencialmente poética.

Decorria o ano de 1901. Em Ponta Delgada os estudantes tomavam a iniciativa de levar a efeito uma subscrição nacional para levantarem um monumento à memória do "poeta-filósofo". Coimbra, onde Antero pontificara durante os anos da sua juventude, reflecte esta iniciativa. No jornal Gazeta Ilustrada, redigido por professores universitários e por bacharéis, no número de 20 de Julho, apoia-se esta ideia, utilizando argumentos de cunho ético-nacional ou mesmo nacionalista. Perante a "crise moral e social" em que o país se encontrava, era preciso ir procurar "coragem" nas "acções dos seus chefes ou nos exemplos dos seus maiores". Assim, deveria ser tomado Antero como exemplo: "O seu perfil psicológico tem grande afinidade com o de muitos santos. E não duvidamos mesmo afirmar que se tivesse vivido noutras épocas pudesse ser hoje adorado nos altares", escrevia o articulista. A imagem queirosiana do "Santo Antero" começava a vir ao de cimo na consciência tradicional.

Afonso Lopes Vieira, que saíra da Universidade no ano anterior, onde se formara em Direito, não só apoiou a iniciativa açoriana, mas também propôs que se levantasse em Coimbra um busto em sua honra. Antero era para Vieira "o poeta de génio", o "modelo da dignidade". Mas, além disso, solidificara a "tradição coimbrã" - uma tradição feita de valor intelectual e de coragem contra a oficialidade. Afonso Lopes Vieira será, aliás, um dos grandes defensores do tradicionalismo coimbrão ao longo de toda a sua vida e foi Antero que, como afirmou, "verdadeiramente fixou a escola de Coimbra, que Luís de Camões criou, e onde todos nos coimbrizamos - escola de almas, que não vem de processos e fórmulas literatas, mas da tradição da mesma terra, do chão que lá pisámos e do ar que respiramos aí" $\left({ }^{15}\right)$.

(15) Gazeta Illustrada, 16.11.1901, "Carta aos estudantes de Coimbra". Sobre as relações entre Afonso Lopes Vieira e Coimbra, vide Aníbal Pinto de Castro, "Coimbra 
Contudo, se Afonso Lopes Vieira não ergueu um edifício tradicionalista teórico de tipo político-social, como António Sardinha, não se confinou também a um mero tradicionalismo coimbrão. Há nele sobretudo uma concepção de tradicionalismo estético, que de resto é já evidente na carta sobre Antero da Gazeta Ilustrada. Mais tarde o seu "depoimento" em artigo do Diário de Notícias, de 28 de Abril de 1920, é bem representativo do que pensava sobre a literatura - a "Literatura de ontem, de hoje e de amanhã", como se intitulou o seu texto. Aí afirma que "o Integralismo Lusitano constitui o mais consciente dos núcleos do pensamento contemporâneo", mas também fala de uma cultura portuguesa feita na base de um forte nacionalismo, de um vincado regionalismo, de um profundo misticismo e de um acendrado sebastianismo. Neste edifício literário de tipo tradicionalista erguem-se as grandes figuras culturais portuguesas, onde pontificam Garrett - a "geração contemporânea" é "afilhada de Garrett" - Camilo, Antero e tantos outros. Antero sintetiza o drama nacional e a voz do profeta: "(...) e esse grande espírito de Antero de Quental, cuja sombra profética passa nestes dias por sobre a nossa angústia, que estende para a memória do herói moral as mãos implorativas afogadas como somos na negação do heroísmo (...)"

Mas, independentemente do problema da autoria da reflexão tradicionalista sobre Antero - mera questão académica - o certo é que foi a posição de António Sardinha que melhor representou essa leitura, até pelo seu comprometimento e pela sua força político-social. Por isso foi ela que acabou por ser retomada e enriquecida, quer pelos neo-integralistas, quer pelos nacionais-sindicalistas, quer mesmo - como veremos mais à frente - pelos salazaristas e até, em certa medida, pelos católicos integristas.

Fernando Campos é o exemplo mais significativo do primeiro grupo. Publicista da causa monárquica, procurou de forma sistemática encontrar as raízes da "Conta-Revolução". Assim, escreveu, entre outras obras sobre o tema, Os Nossos Mestres ou o Breviário da Contra-Revolução (1924), O Pensamento Contra-Revolucionário em Portugal (1931-1933) e No Saguão do Liberalismo (1935). Nelas, como temos dito, tanto são invocados os exemplos de Agostinho de

no pensamento e na obra de Afonso Lopes Vieira", Arquivo Coimbrão, vol. XXVII, Coimbra, 1979, pp. 1-98. 
Macedo, Gama e Castro ou Acúrcio das Neves, como os de Garrett, Herculano, Soriano, Oliveira Martins, Ramalho, Eça, Antero ou Fialho de Almeida. A diferença só reside no seguinte: enquanto os primeiros construíram um pensamento intrinsecamente contra-revolucionário, os outros acabaram por manifestá-lo indirecta ou tardiamente, através das suas "desilusões", da "ironia" das suas críticas ou dos seus "testamentos".

Antero de Quental constituía um caso representativo. O seu "testamento" tradicionalista e antiliberal, ligado a uma aguda consciência crítica e autocrítica e a um pessimismo que não era resultante de um temperamento neuropático mas "de um espírito absorvido pelo temeroso conflito que agitava a sua época" (a maladie du siècle, que também atormentara Henri-Frédéric Amiel, como provara Paul Bourget), é traçado por Fernando Campos através de mais de três dezenas de passos extraídos das suas obras $\left({ }^{16}\right)$. Evidentemente que, através desta estratégia de isolar textos desinseridos de um contexto, era fácil provar que Antero fora efectivamente - como Louis Dimier dissera para o caso de Proudhon - um dos "precursores do tradicionalismo" $\left({ }^{17}\right)$.

- Noutra área diferente, mas com comuns pontos de origem e de confluência, afirmara-se o Nacional-Sindicalismo de Rolão Preto, que pertencera ao grupo inicial do Integralismo. Também ele, em 1942, ano do centenário do nascimento de Antero e em pleno conflito mundial, falava, Para além da guerra - título da obra onde emitiu tais ideias -, do significado do poeta, ou melhor, do "eixo Antero-António Sardinha" e do "seu prolongamento histórico" $\left({ }^{18}\right)$.

Marcado pelas ideias de revolução social ou mesmo de revolução socialista - que estavam para além de uma simples dimensão "estreitamente materialista" e para além da questão do regime político Rolão Preto entendia que esse grito fora lançado primeiro por Antero, em oposição ao fontismo, e depois por Sardinha e pelo Integralismo, como superadores da desilusória revolução republicana. Mas a linha

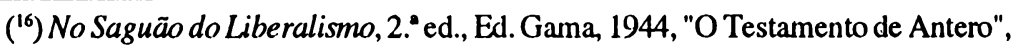
pp. 152-162.

(17) Ob. cit., pp. 150-152.

(18) Para além da Guerra, Ed. Gama, 1942, cap. II, "O eixo Antero-António Sardinha e o seu prolongamento histórico". 


\section{Antero de Quental nas leituras "integralistas"}

Antero-Sardinha teria de ser também superada através de uma "Revolução Nacional-Social", para a qual contribuía o próprio pensamento da Igreja, com as teses do "socialismo católico".

Eis, pois, o motivo por que Antero, como Sardinha, era considerado como "Profeta" e "Mestre". A posição de Rolão Preto pode sintetizar-se afinal nesta interrogação afirmativa com que termina $o$ seu texto:

"Posto isto, não se torna evidente que o eixo ideal Antero de Quental-António Sardinha, em volta do qual se explicam, determinam e resolvem todas as aspirações desta progressiva evolução social contemporânea, veio encontrar na posição espiritual e revolucionária Nacional-Sindicalista o nítido fulcro e o seguro ponto de apoio da sua esperança, do seu natural prolongamento histórico no nosso tempo?" ( $\left.{ }^{19}\right)$.

\section{Os dois Anteros de Alfredo Pimenta}

A mais impressionante interpretação encontramo-la em Alfredo Pimenta. Melhor, encontramos duas interpretações diferentes, que em certo sentido se opõem diametralmente.

Comoésabido, Pimenta foi uma das personalidades mais singulares deste século. Começou no anarquismo, passou para o evolucionismo republicano de António José de Almeida, mas, à volta do fim do primeiro lustro da República, admitindo que não era possível a tranquilidade e a ordem, converte-se à causa monárquica. Logo no primeiro ano de publicação da revista Nação Portuguesa, em 1914, vêmo-lo ali a publicar os seus artigos. Mais tarde apoiou o Estado Novo, mas mantendo sempre uma posição radical e crítica, que constituiu de resto a sua postura naturál. Daí as suas inúmeras polémicas com sectores diversos, entre os quais as próprias famílias "situacionista" e "católica".

Este intelectual complexo - a exigir um estudo de alguém que objectivamente analise a sua personalidade e a sua obra - teve, na verdade, um comportamento sui generis em relação a Antero de Quental. Os textos de 20 dão-nos a imagem de um Antero aureolado com os

$\left.{ }^{19}\right)$ Ob. cit., p. 36. 
louros do génio e, ao contrário, nos anos 40 encontramos um Antero moral e socialmente deleterio.

Alfredo Pimenta, pelos textos que conhecemos, não seguiu a estratégia de Sardinha, fazendo de Antero um dos mestres da Contra-Revolução, mas apresentou-o como o "poeta genial". Devido à sua formação e às posições políticas que primeiro assumiu, no seio do anarquismo coimbrão e do republicanismo, é natural que Antero tivesse sido o seu poeta de cabeceira. Assim o confessa num texto de 1920: "Foi seguramente o meu primeiro poeta amado e foram os seus versos que eu mais religiosamente decorei em toda a minha vida" $\left({ }^{20}\right)$. É certo que já afirmava então detestar o filósofo e o revolucionário das Odes Modernas, mas também procurou salientar que Antero jamais acreditou na revolução, porque a encarava numa perspectiva moral e superior e olhava apreensivo a sociedade portuguesa.

Noutro texto publicado em 20 os elogios são ainda maiores, como se vê através deste passo lapidar:

"Poeta, - não o houve maior na terra portuguesa, não o houve maior em terra alguma do mundo.

Prosador, - é dos melhores.

Espírito filosófico, - é dos mais agudos e transcendentes.

Homem, - é dos mais perfeitos, pela Justiça, pela Humanidade. A sua vida é uma página do flos sanctorum.

Tão bom ele foi, que creio bem que nunca Deus lhe levou a mal as blasfémias da mocidade inquieta, as dúvidas do pensamento angustiado.

A sua obra de Poeta é pequena, - mas imortal. Os sonetos são o mais belo documento poético que a Raça portuguesa pode apresentar.

Antero é maior do que Camões" $\left({ }^{21}\right)$.

Era esta "memória sagrada" de Antero que Alfredo Pimenta, na qualidade de "Artista" (como ele se considerava), guardava religiosamente. Recitava os sonetos espirituais "À Virgem Santíssima" e "Na Mão de Deus" ou a "tragédia psíquica" de "O Palácio da Ventura", e amava em Antero, no seu dizer, "a Beleza que não morre". O próprio "decadentismo doentio" do poeta era por ele intrinsecamente entendi-

$\left({ }^{20}\right)$ O livro de muitas e variadas coizas escripto por Alfredo Pimenta, Lisboa, Parceria António Maria Pereira, 1920, p. 164.

(21) Sombras de Príncipes (Garrett e Herculano, Camillo, Anthero de Quental, João de Deos, Antonio Nobre, Cezario Verde), Lisboa-Rio de Janeiro, Portugalia Editora,1920, p. 34. 
do, pois considerava-o como "condição fundamental, essencial, de Arte" ( ${ }^{22}$ ). Mas amava sobretudo o "Santo Antero", "a mais bela, a mais gentil figura literária da Vida portuguesa". Assim, concluía num dos seus textos que estamos a seguir: "Leio os seus Sonetos, rezando-os, e quando os leio, esqueço as maldades, as intrigas, as mesquinhices e os pequenos episódios deste mundo que não foi feito para compreender e amar nem os Artistas, nem os Heróis, nem os Santos!" $\left.{ }^{23}\right)$.

Mas vejamos agora o que disse e escreveu Alfredo Pimenta numa conferência proferida em 1 de Março de 1941 em Braga.

Comecemos pelo panorama que nos dá das gerações de 70-80 em que não fala ainda concretamente de Antero de Quental. Extractemos um texto sintomático: "Os verdadeiros e enérgicos dissolventes da Sociedade portuguesa, no campo da Inteligência, foram Eça de Queirós e Ramalho, no panfleto das Farpas, secundados, dez anos depois, por Fialho nos Gatos; Guerra Junqueiro, na Poesia; Rafael Bordalo, na Caricatura; Oliveira Martins, na História; Eça de Queirós, sozinho, no Romance. É uma equipa de autênticos malfeitores do Espírito - e tanto mais perigosos, quanto é certo que foram homens de real valor" $\left({ }^{24}\right)$.

E Antero de Quental?

Responde Alfredo Pimenta: "Antero, do alto da excelsitude da sua grandeza moral, esse que nos diziam ser Santo e modelo de homens, bradava-nos em termos inequívocos, que o verdadeiro patriotismo nos impunha o dever de renegar a nacionalidade. Tal qual: 'renegar a nacionalidade"' $\left({ }^{25}\right)$.

Repare-se que agora Pimenta isola sobretudo as lutas iberistas do Antero político. Não deixa de o considerar "genial" - a sua contradição não chegou a tanto - mas, notando que "o génio não é incompatível com o mal, nem impermeável ao desvario", afirma também que foi um "pensador péssimo: sempre fulgurante - mas sem bússola nem norte" $\left({ }^{26}\right)$.

Mesmo os Sonetos, que tanto apaixonaram Pimenta, levam-no a

\footnotetext{
${ }^{(22}$ Cfr. O livro de muitas e variadas coizas, p. 166.

$\left({ }^{23}\right)$ Sombras de Príncipes, p. 41.

$\left({ }^{24}\right)$ Mestres do Pensamento. Conferência realizada no Ateneu Comercial de Braga no dia 1 de Março de 1941. Braga, Ateneu Comercial de Braga, s.d., p. 22.

${ }^{(25)}$ Conf. cit., p. 23.

${ }^{(26)}$ Idem, p. 24.
} 
considerações cronológicas, que muito interessam por essa mesma altura Bruno Carreiro e Costa Pimpão. Já não era o Pimenta "artista" que falava, mas o Pimenta "cientista". Assinalou a "falsificação" da ordenação dos sonetos, levada a efeito pelo próprio Antero. E, além disso, renegou, ele próprio, seu leitor apaixonado desde os 15 anos, a sua devoção pelo poeta, que tanto mal lhe causou $\left({ }^{27}\right)$.

Pimenta é acima de tudo, pelos anos 40, o "nacionalista" radical vogando nas águas do "fascismo", que não perdoa o "antinacionalismo" de Antero: "Não, senhores da geração nova! Não tomem como Guia e Modelo aquele que escreveu ser 'duvidoso se haverá posteridade para este deplorável Portugalório de hoje"' $\left({ }^{28}\right)$.

\section{Antero entre a "graça" e o "pecado" - a visão do Catolicismo Integrista}

A posição dos "católicos" em relação a Antero tem, como se disse, uma preocupação de natureza essencialmente religiosa. É neles evidente a seguinte questão: Antero de Quental, apesar das suas posições iconoclastas, foi católico? - Católico na sua moral e no fundo da sua consciência ou católico na qualidade de "convertido", ou mesmo como um homem que, vencido pela vida, através de uma morte anticristã, o suicídio, terá procurado a "Verdade" e repousado na "mão de Deus"? Ou, ao invés, foi antes um "apóstata", que repudiou a sua educação tradicionalmente católica, levado pelos "males do século"?

OPadre Sena Freitas, conhecido legitimista e católicoultramontano e que havia sido condiscípulo de Antero, escrevera, pouco antes da sua trágica morte, que ele era um caso "tristemente célebre". E afirmava: "Repugna-me adverbiar de um modo tão pouco favorável a reputação literária de um patrício meu; mas não posso levar a bem que ele pusesse o seu muitíssimo talento ao serviço da mais desoladora das filosofias, da filosofia schopenhauriana. Hoje julgo que não trata mais de fazer filosofia nem poesia, mas simplesmente boa hematose ou boas carnes" $\left({ }^{29}\right)$.

Porém, esta visão truculenta e panfletariamente negativa da persona-
(27) Idem, pp. 24-26.
${ }^{(28)}$ Idem, p. 26.
${ }^{(9)}$ Observaçōes Críticas, vol. I, 1888 , p. 3, cit. in P. Moreira das Neves, $O$ Grupo 
lidade de Antero não era vulgar nos meios católicos, como já observámos atravess da análise das interpretações dos integralistas lusitanos, também eles católicos afinal. Mas vejamos agora alguns exemplos mais significativos do movimento católico "oficial", dos anos 30-40, situado no que poderemos chamar a linha "integrista".

Gonçalves Cerejeira, professor da Faculdade de Letras de Coimbra e depois Cardeal-Patriarca, e amigo íntimo de Salazar, é um dos exemplos mais representativos deste sector. Num capítulo de uma colectânea de textos escritos durante os seus tempos de Coimbra, em que procurou mostrar que a "renascença cristã" sobreveio ao "mal do século", deixa-nos breves considerações sobre Antero, o "genial Antero" (como lhe chama). A imagem que nos apresenta é a do "poeta-filosofo" que dramaticamente sentiu a "dor" e a "revolta do frio estiolante da dúvida" e que so "descansou" em Deus. Mas "só por um momento" - "a Ilusão voltou para no-lo roubar numa hora fatal, maldita, de desespero, à Pátria e às letras" $\left({ }^{30}\right)$.

Ideia idêntica sobre Antero é emitida no polémico livro A Igreja e o Pensamento Contemporâneo, cuja primeira edição saiu em 1924. "Foi com a geração de 1870 que o 'estúpido século XIX', como brutalmente diz Léon Daudet, chegou a Portugal" - esta é a base da reflexão crítica de Cerejeira $\left({ }^{31}\right)$. E passou a descrever os indícios dessa "estupidez": Antero, "imprecando amargamente a Divindade"; Eça, "com o fino florete da sua ironia, sorrindo"; Ramalho, "ostentando a nova ciência, como novos ricos os maços de notas de banco"; Junqueiro, "com os explosi vos dos seus sarcasmos, blasfemando"; Oliveira Martins, "instilando pela análise crítica o racionalismo pessimista do tempo"; Teófilo, "cuja considerável obra críticaé viciada (além das insuficiências do método crítico) pelo ódio à Igreja"; Camilo, "cuja vida trágica caminhou tempestuosamente atraída sempre pelo abismo"; Fialho de Almeida, "que atacou a sociedade do seu tempo como os garotos, apedrejando e assobiando"; Gomes Leal, "cuja poesia foi como uma flor vermelha de irreverência e blasfémia" ${ }^{32}$ ).

Utilizando, porém, a tese da "conversão" - ideia sempre presente

dos Cinco. Dramas espirituais, Lisboa, Livr. Bertrand, 1945, pp. 32-33.

$\left({ }^{30}\right)$ Vinte anos de Coimbra, Ed. Gama,1943, "Renascença Cristã", pp. 23-24.

${ }^{(31)}$ A Igreja e o Pensamento Contemporâneo, Coimbra, Coimbra Editora, 1928 (2." ed.), p. 275.

$\left.{ }^{32}\right)$ Ob. cit., pp. 277-278. 
no pensamento católico - Cerejeira procurou encontrar nestes "intelectuais orgulhosos" a marca do "arrependimento", ou, pelo menos, de uma tortura intelectual que apontava para os novos caminhos da "renascença cristã". Assim, diz expressamente de Antero: "acabou num acto de desespero - mas saudando a nova espiritualidade que pressentiu". A dramática procura da verdade só o poderia conduzir ao Cristianismo, de onde saíra: "Errando sempre, através de sistemas, a sua alma incrédula só podia, porém, repousar na mão de Deus..." ${ }^{\left({ }^{33}\right)}$.

Esta sugestão de Cerejeira, como de resto toda a estrutura de pensamento do seu livro, provocou viva polémica no seiodos intelectuais republicanos, formados nas teses laicistas. Sílvio Lima, também professor da Faculdade de Letras de Coimbra, escreveu a propósito longas "notas críticas", numa das quais rebateu o alegado cristianismo de Antero ou o afirmado percurso do escritor a caminho da "renascença cristã". A questão da cronologia dos sonetos era um dos argumentos de Sílvio Lima, como o será, curiosamente, de alguns intelectuais católicos, que também porão em dúvida o cristianismo de Antero. O soneto $\mathrm{Na}$ mão de Deus, tido como testemunho da "conversão", é de 1882 - afirma, recorrendo ao testemunho de Bruno Carreiro-, não se reportando, por conseguinte, à fase final do percurso espiritual do poeta $\left({ }^{34}\right)$.

Trindade Salgueiro, um outro dos grandes expoentes da intelectualidade católica, que veio também a ser professor da Faculdade de Letras de Coimbra e depois bispo, ocupando vários lugares importantes na hierarquia da Igreja, interveio activamente nessa polémica do princípio da década de 30 e nela prolongou as teses de Gonçalves Cerejeira. Ali coleccionou vários argumentos e testemunhos sobre a espiritualidade de Antero, afirmando: "Nos últimos anos da sua vida, porém, olhava com sincera simpatia a Religião de que se afastara. 'Espírito naturalmente religioso', como ele confessa (...), se a doença o não tivesse arrastado à dolorosa tragédia que todos conhecemos, talvez viesse a praticar a fé viva da sua mãe, como sucedeu a outros nobres espíritos da sua geração". Antero "morreu a caminho da Igreja?" - a interrogação de Trindade Salgueiro, e de Ce-

$\left({ }^{33}\right)$ Idem, pp. 279-280.

$\left({ }^{34}\right)$ Notas críticas ao livro do Sr. Cardial Gonçalves Cerejeira "A Igreja e o Pensamento Contemporâneo", Coimbra, Livraria Cunha, 1931, pp. 16-18. 
rejeira, esboça no fundo uma certeza, mais do que um sentido de dúvida $\left({ }^{35}\right)$.

Outros escritores católicos bem representativos continuaram a reflectir sobre o drama espiritual de Antero de Quental em termos idênticos. Basta citar mais dois: Lúcio Craveiro da Silva, jesuíta e superior provincial da Companhia, e director da Faculdade de Filosofia de Braga, depois integrada na Universidade Católica, e Francisco Moreira das Neves, que desde 1934 foi chefe de redacção do jornal católico Novidades e que mais tarde veio a pertencer ao Conselho de Programas da Radiotelevisão.

Aoprimeirodeve-se uma obra fundamental sobreo"poeta-filosofo", Antero de Quental. Evolução do seu Pensamento Filosófico $\left({ }^{36}\right)$. Não é, porém, sobre este livro, publicado em 1959, que nos vamos debruçar brevemente. A questão religiosa em Antero vinha sendo analisada desde há muito por Craveiro da Silva na mais importante revista católica portuguesa, Brotéria. No artigo "O 'problema vital' de Antero", publicado no ano do centenário do seu nascimento, o intelectual jesuíta torna a reflectir sobre a tragédia do poeta, que - a seu ver - "não solucionou a guerra íntima da sua alma", não encontrando "o sentido da vida". Mas, se não alcançou "a paz da alma e da consciência, guiado pelas exigências da pureza ontológica, que interiormente lhe comandavam o espírito", foi porque - Craveiro da Silva recorria à velha argumentação de Sardinha - "certos resíduos evolucionistas, deixados no seu pensamento pela grosseira superstição do Progresso, impossibilitaram Antero de encontrar, no Catolicismo, a incógnita da questão que tanto o assombrava e suspendia". E assim concluía: "Por isso, deixou a vida em aberto, na dolorosa atitude em que o poeta nos pinta o náufrago, lançando a mão para a praia salvadora..." $\left({ }^{37}\right)$.

Este Antero dividido entre a "lógica do sentimento e do coração" e o "canto sedutor" da Razão, volta a ser pensado, de forma idêntica, pelo

(35) Um livro infeliz..., Coimbra, Tip. Alves e Mourão, 1931, p. 123 ss., especialmente nt. 2.

${ }^{(36)}$ Antero de Quental. Evolução do seu pensamento filosófico, Braga, Livraria Cruz, 1959.

$\left.{ }^{(37}\right)$ "O 'Problema vital' de Antero", Brotéria, vol. XXXV, fasc. 4, Abril 1942, p. 369. 
futuro monsenhor de Pio XII, Moreira das Neves, num livro em que abordou os "dramas espirituais" do "Grupo dos Cinco" (Antero, Oliveira Martins, Eça, Ramalho e Guerra Junqueiro). Situando-se num plano essencialmente teológico, Moreira das Neves analisa a questão da "história do homem" como um processo de libertação do "pecado" ede reencontro com Deus. Anteroé, pois, um dos exemplos "dramáticos" analisados pelo autor.

Aborda assim a sua "história", marcada contraditoriamente pela fé e pela heresia. A Graça esteve sempre nele presente, mas Antero não conseguiu encontrar o "caminho". "Sofrendo, como o Platão dos Diálogos, - sintetiza Moreira das Neves - de incessante crise da razão e da sensibilidade, faltou-lhe, para desenigmatizar a sua propria vida, a humildade de um Santo Agostinho ou de um Pascal, - virtude fecunda e eminentemente coordenadora dos esforços humanos para a resolução daquelas dificuldades e interrogativas que perseguem todos os intuitivos de génio" $\left.{ }^{38}\right)$.

Mas, apesar disso, apesar do suicídio, Antero ter-se-á salvo? Moreira das Neves assim acredita, recorrendo ao testemunho interrogativo do Padre Jerónimo Filomeno Veloza, que lavrou a acta do óbito e que ali escreveu: "Quem sabe se o exímio poeta no último e lancinante volver de olhos se dirigiu ao criador invocando a piedade e o perdão?" ( ${ }^{39}$ ) "Suicídio sob a âncora", a âncora da Esperança, a Esperança da Salvação - eis uma imagem da morte, e da vida, de Antero, bem representativa do pensamento "católico".

\section{O Socialismo de Antero e as "interpretações de regime"}

O próprio pensamento social de Antero pôde gerar interpretaç̃es de sentido cristão, que correspondem, em certa medida, ao fundo do seu pensamento. Efectivamente, não deixa de nos surpreender à primeira vista - tendo em conta que nos referimos ao período cronológico salazarista, caracterizado por um anti-socialismo sistemático - a importância que é conferida ao "Socialismo de Antero de Quental". No entanto, depois de bem analisados os textos, compreendemos o motivo

${ }^{(38}$ ) "Antero ou o suicídio sob a âncora", in O Grupo dos Cinco, Lisboa, Livr. Bertrand, 1945, p. 51.

$\left({ }^{39}\right)$ Idem, p. 54. 
desse interesse: em alguns deles o que se procurou afinal encontrar no socialismo de Antero foi um fundo cristão e corporativo.

Nãoé isso exactamente que sucede numa dissertação de licenciatura apresentada à Faculdade de Letras de Coimbra nos anos 40 por Ângelo Raposo Marques, $O$ Socialismo de Antero, obra que veio depois a ser publicada postumamente em $1959\left({ }^{40}\right)$. Orientado por um dos maiores anterianistas universitários, o Professor Joaquim de Carvalho, eajudado pelo melhor biógrafo do escritor, Bruno Carreiro, o autor procurou explicar "cientificamente" o socialismo de Antero de Quental. É claro que não deixou de ligar as concepções socialistas e os métodos revolucionários defendidos pelo escritor ao cristianismo, mas, seguindo a via interpretativa de Joaquim de Carvalho, não viu em Antero um pensador essencialmente cristão e muito menos um "contra-revolucionário", à maneira de Sardinha. Encarou-o na sua linha de socialismo utópico, de tipo proudhoniano; viu-o, nessa perspectiva, como um revolucionário; interpretou-o como um antijacobino, mas como um republicano convicto.

Já não é bem essa a visão que aparece no texto do publicista José Tomás de Sousa, O Socialismo e Antero de Quental, editado nesse ano de 1942, do centenário do nascimento do poeta. É certo que é António Sérgio e Joaquim de Carvalho que servem especialmente de base aos argumentos do autor; no entanto, parece haver nele uma outra intenção bem manifesta: não só provar a oposição de Antero ao socialismo materialista de Marx - o que, de resto, era uma evidência, também afirmada por Joaquim de Carvalho e Ângelo Raposo Marques -, mas também o seu "anti-revolucionarismo", a sua defesa da propriedade individual resultante do produto do trabalho, no contexto da "justiça social", e a raiz essencialmente cristã do seu "socialismo". Contudo, mesmo assim, o autor, que dedicou a maior parte do seu trabalho a definir os vários tipos de socialismo, a caracterizar historicamente as diversas escolas socialistas e a analisar a história do socialismo em Portugal e no mundo, para só dedicar uma pequena parcela do livro a Antero, não deixou de discutir o seu pensamento socialista, ou mais concretamente, o colectivismo que ainda encontrou no poeta social.

$\left({ }^{40}\right)$ O Socialismo de Antero. Ensaio. Ponta Delgada, Instituto Cultural de Ponta Delgada, 1959. 


\section{Antero de Quental}

É interessante, com efeito, ler textualmente as palavras do ensaísta neste particular. Eis como ele, de forma presentista, critica Antero: "A parte mais socialista do seu pensamento - a colectivização dos instrumentos de produção - é exactamente aquela que mais se acha em contradição com a ideia de justiçae as conclusões da ciência económica. Considerar o trabalho a única fonte de riqueza - usando da dialéctica de Antero - é coisa que a consciência diz, não pode ser e a economia política acrescenta, não deve ser. Se na organização capitalista, por ele criticada, há capitais que recebem lucros indevidos, isto não quer dizer que o capital seja improdutivo. O capital produz riqueza exactamente como o trabalho: se não pode dispensar o trabalho para a obter, também este o não pode dispensar para a obra da produção. Extinguindo-se o capital privado, segundo o sistema de Antero, necessário se torna substituí-lo pelo capital público o que, só por si, demonstra a inexactidão do princípio de onde se parte. $O$ que a justiça e a Ciência nos levam a concluir é que sendo ambos necessários para a criação da riqueza, não deve um dos factores dominar o outro, cabendo a cada um especial função" $\left.{ }^{41}\right)$.

O objectivo do autor consiste, pois, em defender uma tese de "terceira via", ao mesmo tempo anti-individualista e anti-socialista, uma prática corporativista e personalista, de conciliação entre o Capital e o Trabalho, entre a intervenção do Estado e a iniciativa da Nação. Numa palavra: o seu pensamento articulava-se com a teoria do Estado Novo.

Neste sentido, procurou ver no socialismo de Antero uma tese o mais próxima possível dessa teoria. Mas não se coibiu de "intervir" no seu pensamento social, para o criticar no ponto que entendeu mais afastado das "teses de regime".

\section{Antero precursor da "Revolução Nacional" - a leitura do Estado Novo}

O Panteão Nacional, inaugurado em 1966, já em tempo de crise do Estado Novo, não conta, entre os "grandes homens mortos" ali sepultados, com Antero de Quental. Não queremos dar a esta nossa

( ${ }^{41}$ ) S Socialismo e Antero de Quental, Lisboa, Livraria Clássica Editora, 1942, pp. 77-78. 
afirmação um sentido especial, mas tão só constatar um facto.

Com efeito, sãoescassos os portugueses ilustres que ali se encontram para podermos tirar daí uma ilação significativa. E devemos ter em atenção também que, se o Panteão de Santa Engrácia só aparece no período salazarista tardio, existiu primeiro o dos Jerónimos, desde 1880 , datando de 1836 o decreto-lei que instituiu o panteão.

Os escritores ali sepultados são apenas três: Garrett, João de Deus e Guerra Junqueiro, permanecendo Alexandre Herculano no antigo Panteão de Belém. Antero repousa humildemente no cemitério de São Joaquim, em Ponta Delgada, como sucede com tantos outros escritores ilustres, que estão sepultados nos cemitérios das terras onde nasceram ou de outros quaisquer lugares a que ficaram ligados.

Este facto não significa porém - já o verificámos - que Antero de Quental não fosse considerado uma "glória nacional", quer pelo Estado Novo, quer pelos regimes anteriores.

Conforme brevemente anotaremos, depois da sua morte, em 1891, muitas manifestações lhe foram feitas por gregos e troianos, isto é, pelos vários regimes e por homens de todas as ideologias. Mas, falando agora apenas da imagem oficial que de Antero deu o Estado Novo, salientemos para já que ele é sempre representado como figura de primeiro plano das letras e da história nacionais.

Bastaria um exemplo significado para comprovar esta afirmação evidente.Pouco depois de ter sido fundadoo Secretariado de Propaganda Nacional (S.P.N.), liderado por António Ferro, foram instituídos para o ano de 1933-34 os "Prémios Literários". Utilizando uma estratégia de assimilação já por nós referenciada, foram-lhes atribuídos - e a outros que depois foram criados - nomes de "figuras nacionais", algumas delas de "ortodoxia duvidosa", como Eça de Queirós, Antero de Quental, Ramalho Ortigão ou Fialho de Almeida. Aliás, em relação a Eça, Ferroproferiu um discurso interessantíssimo, em que procurou mostrar que ele não podia abusivamente ser considerado um escritor revolucionário, mas apenas como um grande homem das nossas letras $\left({ }^{42}\right)$.

O prémio de poesia teve exactamente como patrono Antero de Quental. E curiosamente o seu regulamento estipulava que ele seria

${ }^{\left({ }^{42}\right)}$ Eça de Queirós e o Centenário do seu Nascimento, Lisboa, S.N.I., 1949, especialmente p. 17. 
concedido, em duas categorias, ao "melhor livro de versos" e a "um poema ou poesia solta" em que "se revele uma inspiração bem portuguesa e mesmo, de preferência, um alto sentido de exaltação nacionalista" $\left({ }^{43}\right)$. Antero aparecia, assim, a patrocinar um prémio de poesia preferencialmente de vocação nacionalista, tendo sido concedidos galardões, entre outros, aos seguintes livros ou poemas e poetas: Mensagem de Fernando Pessoa e A Romaria do Padre Vasco Reis (1934), Desaparecido de Carlos Queirós (1935), Confidências de um Rapaz Provinciano de Azinhal Abelho (1936), Portugal de Ramiro Guedes de Campos (1937), Resgate de Miguel Trigueiros (1938), Segredo de Pedro Homem de Melo (1939), A Alma e o Deserto de Américo Cortez Pinto (1941), Navio na Montanha de Campos de Figueiredo (1942), Cancioneiro de Cabral do Nascimento (1943), Batuque de Guerra de Amândio César (1945), Manta de Retalhos de Maria Teresa Andrade Santos (1946), Rio Infindável de Natércia Freire (1947), A Seiva do Mistério de Ribeiro Dias (1948) $\left({ }^{44}\right)$.

Diga-se ainda, relativamente aos prémios do S.P.N. - chamado S.N.I. (Secretariado Nacional de Informação, Cultura Popular e Turismo) em fins de 1944, quando o avizinhar do termo da guerra e a derrota prefigurada do Eixo faziam aconselhar o desaparecimento de nomes de conotação fascista-que o notável estudo Antero de Quental, de José Bruno Carreiro, recebia em 1948 o prémio de ensaio "Ramalho Ortigão", e a obra No saguão do Liberalismo, de Fernando Campos, que continha, como vimos, uma interpretação integralista de Antero, foi agraciada em 1935 com o prémio de doutrina ou polémica "António Ennes" $\left({ }^{45}\right)$.

Mas não era só através dos prémios de S.P.N./S.N.I. que se "reproduzia" o nome da grande "figura nacional" que era Antero de Quental. As próprias edições desse órgão divulgaram a poesia $e$ a prosa escolhidas e estudos sobre a personalidade complexa, mas de valor indiscutível, de Antero. Como exemplo significativo dessa acção cite-se, antes de mais, a obra Antero de Quental, selecção de textos e

${ }^{\left({ }^{43}\right)}$ António Ferro, A Política do Espírito e os Prémios literários do S.P.N. Discurso pronunciado em 21 de Fevereiro de 1935, Lisboa, S.P.N., s. d. [1935], pp. 29-30.

${ }^{(44)}$ Ob. cit., pp. 215-216.

$\left({ }^{45}\right)$ Cfr. ob. cit., respectivamente, pp. 215 e 217. 


\section{Antero de Quental nas leituras "integralistas"}

prefácio de José Calvet de Magalhães, publicada na colecção "Idearium. Antologia do Pensamento Português" em $1948\left({ }^{46}\right)$.

Fundamentalmente o que pretende relevar Calvet de Magalhães, quer no estudo sobre o pensamento de Antero, quer nos textos anterianos seleccionados, é que o escritor defende vivamente uma "filosofia espiritualista". A sua interpretação pode sintetizar-se neste texto: "A crítica que dirigiu ao positivismo e ao materialismo dominantes aproxima-o dos reconstrutores da Metafísica contemporânea e é sumariamente honrosa para o seu esforço de pensador, não só como reveladora de inegáveis qualidades de independência espiritual, como denunciadora de uma segura, se bem que incompleta presciência da evolução espiritual futura. No campo social e político, sem se furtar à influência socialista da época, repudiou no entanto a concepção materialista da história, proclamando o primado da moral e defendendo a estrutura fundamental da sociedade europeia, para a qual preconizava apenas uma renovação no sentido das ideias de Proudhon" $\left({ }^{47}\right)$.

Como se vê, Antero aparece aqui como um quase precursor da "evolução espiritual futura" e um defensor da ética como elemento essencial da política. Aliás, também em Calvet de Magalhães se procura reduzir o elan revolucionário de Antero, limitando-o a uma simples posição reformista: "O seu eticismo e a sua preocupação reformadora - e não revolucionária - pela descentralização e a associação, aproximam-no muito mais do socialismo cristão do que qualquer outra escola do socialismo contemporâneo" $\left({ }^{48}\right)$.

Mas esta observação não implicava que também não encontrasse deficiências profundas no pensamento de Antero. Falta "qualquer coisa" no seu sistema filosófico, marcado pela influência do dinamismo de Leibniz, do criticismo de Kant e do idealismo de Hegel. "Essa qualquer coisa é a ideia de Deus" - concluía $\left({ }^{49}\right)$.

A escolha dos textos de Antero é feita por Calvet com intuitos evidentes. Sobretudo isso é claro quando selecciona os passos referentes ao seu "pensamento social". O que se pretende salientar, através de excertos saídos das Prosas, é que Antero se pronuncia contra a

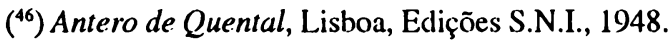

$\left({ }^{47}\right)$ Ob. cit., pp. 9-10.

$\left({ }^{48}\right)$ Idem, p. 20.

$\left({ }^{49}\right)$ Idem, p. 28. Cfr. pp. 23-28.
} 
burguesia liberal - "a aristocracia do dinheiro e da propriedade" - tem uma política nacional e não partidária - "seguimos o Povo, não seguiremos nenhum partido e, num certo sentido, nenhuma escola"-, defende uma "ideia nova", que tem como objectivo essencial a defesa dos valores éticos nacionais - "o levantamento da vida moral da nossa querida Pátria" $\left({ }^{50}\right)$.

Calvet de Magalhães não considerou explicitamente Antero de Quental, como outros o farão, "precursor da Revolução Nacional", mas deixou-nos sugestões que apontavam para aí.

Também há algumas sugestões nessa direç̧ão - talvez, no entanto, ainda menos evidentes do que em Calvet de Magalhães - no texto que o jornalista e publicista Luiz Teixeira, o único verdadeiro divulgador da biografia de Salazar $\left({ }^{51}\right)$, escreveu por altura do centenário de Antero. A Vida de Antero de Quental não se pode dizer, no entanto, que seja um "texto de regime". Quando muito, neste perfil de Antero e na intenção da publicação de algumas das suas cartas, entre elas a famosa epístola autobiográfica a Wilhelm Storck, poderemos perscrutar as imagens da vida de "um génio" que teve as suas "estouvanices da mocidade", que se apaixonou por uma revolução moral e cristã e que criticou os republicanos portugueses e que, depois de trágicos problemas de consciência, muito afectado pela doença e pelo seu misticismo, acabou por se suicidar. No entanto, apesar deste final sombrio, Luiz Teixeira, que salientou por diversas vezes a "santidade" de Antero, terminou o seu texto com uma imagem de Esperança:

"Desde então, pelos tempos fora, as gerações que chegam recordam Antero repetindo sempre:

Dorme o teu sono, coração liberto

Dorme na mão de Deus eternamente!" ${ }^{(52}$ )

Mas Antero há-de aparecer colado à ideia do Estado Novo, assim

$\left({ }^{50}\right)$ Cfr. sobretudo pp. 109-115.

(51) Perfil de Salazar. Elementos para a história da sua vida e da sua época, Lisboa, Edição do autor, 1938.

(52) Vida de Antero de Quental, Lisboa, Livraria Clássica Editora, 1942, p. 30. 
como em Sardinha foi interpretado como precursor da Contra-Revolução.

Assim sucede numa coleç̧ão bem significativa, os "Cadernos do Quadragésimo Ano", que celebravam os quarenta anos da "Revolução Nacional". O texto é da autoria de João Afonso e o título é um verdadeiro programa: Antero de Quental e o Pensamento da Revolução Nacional.

Acima de tudo o que o autor pretende revelar é um Antero de Quental devotado à ideia de "salvar Portugal", através de uma "Revolução Nacional". Todo o texto procura aproximar essa "ideia anteriana", de uma revolução nacionalista e ética, da ideia que assoma em 26 e daquela que foi depois corporizada por Salazar. Não eram precisas palavras expressas, mas elas também lá estão: "A Nação estava, efectivamente, doente. O diagnóstico que Antero apontou eque seria reafirmado, trinta anos depois, em plena Sala do Risco, veio a indicar qual o tratamento a aplicar: 'o momento da acção' chegava em 1926" $\left({ }^{53}\right)$.

É o "texto de regime" mais significativo, ainda que outros, com as suas sugestões, façam eco das ideias-força do Estado salazarista. $\mathrm{O}$ "perigo comunista", o "perigo russo", era, como se sabe, uma dessas ideias. Também ela foi entrevista por certos ideólogos em Antero, como, naturalmente, em António Sardinha - o eixo Sardinha-Antero da concepção "integralista" ou "neo-integralista" voltava sempre ao de cimo. A revista Panorama, do S.N.I., publicou em 1960 um ensaio do anterianista Ruy Galvão de Carvalho onde aparecem essas imagens salazaristas esbatidas nas sugestões daqueles que eram considerados seus "precursores" $\left({ }^{54}\right)$.

7. Antero lido aos jovens e aos adultos - o ensino e a divulgação no Estado Novo

Já falámos alguma coisa sobre a divulgação de Antero no Estado

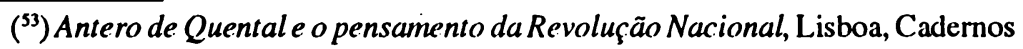
do Quadragésimo Ano, 1967, p. 19.

( ${ }^{\text {s4 }}$ Ruy Galvão de Carvalho, "Antero de Quental e António Sardinha profetas do perigo eslavo", Panorama. Revista Portuguesa de Arte e Turismo, n. ${ }^{\circ} 20$, III série, Dez. 1960. 
Novo. Mas diremos ainda algo mais, centrando-nos sobretudo na área do ensino.

Antes, todavia, recordemos que a imagem divulgada pelo órgão de propaganda do regime, o S.P.N./S.N.I., era a do "Antero nacionalista", como também a do "Antero espiritualista".

Foi essa afinal a imagem reproduzida numa obra interessantíssima, e verdadeiramente paradigmática, dirigida aos emigrantes portugueses (aos "portugueses do Brasil, da Argentina, dos Estados Unidos da América do Norte, da India, da China e a tantos outros compatriotas que vivem em terras longínquas"), como tambem aos "portugueses do Império". O título sintetiza a intenção explicada em prefácio por António Ferro, Portugal. Breviário da Pátria para Portugueses Ausentes. Publicada em 1946, ano de uma relativa abertura do Estado Novo, tem uma colaboração variada, onde, a par de "intelectuais de regime" ou de fundo "tradicionalista" - como João Ameal, Marcello Caetano, Luiz Teixeira, José Osório de Castro -, se encontram cientistas e pensadores com posições independentes, tais como Orlando Ribeiro ou Delfim Santos.

Delfim Santos, professor de Filosofia e Pedagogia na Faculdade de Letras de Lisboa e discípulo de Leonardo Coimbra, escreveu o capítulo sobre o pensamento filosófico português. A imagem de Delfim Santos não destoa, porém, da ideia de Antero di vulgada pelo Salazarismo, sem com isto querermos dizer que se trata de uma "imagem de regime". É curto o texto que lhe dedica. Apenas pretende salientar o seu anti-positivismo, a sua crítica parcial ao mecanicismoe a sua adesão fundamental ao espiritualismo. "O seu espiritualismo - escreve Delfim Santos - põe a descoberto, e revela em forma admirável, um dos aspectos permanentes do pensamento nacional e fixa as suas principais coordenadas no lirismo, de que ele é um dos mais excelsos representantes" ( $\left.{ }^{55}\right)$.

No capítulo referente à literatura - que de resto constituiu um volume independente, de divulgação para estrangeiros $\left({ }^{56}\right)$ - José Osório de Oliveira apresenta-nos a imagem do Antero "romântico", do Antero "místico", do Antero "crente", do Antero "que não foi filósofo", numa palavra, do Antero poeta. "Poeta, e grande poeta, dos maiores da

${ }^{(55)}$ Portugal Breviário da Pátria para Portugueses Ausentes, Lisboa, Edições SNI, 1946, pp. 270-271.

${ }^{(56)}$ Panorama de la Littérature Portugaise par José Osório de Oliveira. Texte et citations traduits par Jean Bayle. Lisbonne, Éditions SNI, s.d. 


\section{Antero de Quental nas leituras "integralistas"}

língua portuguesa e um dos nossos raros poetas universais - eis o que ele foi", são estas as palavras de síntese $\left({ }^{57}\right)$.

Merece também a nossa atenção a colectânea de poesia organizada na segunda metade da década de 50 por José Régio para a "Coleç̧ão Educativa", da Campanha Nacional de Educação de Adultos. De Antero escolheu o soneto "Solemnia Verba", que Régio comenta, notando que o poeta, depois de um caminho de Dor que havia percorrido, julga que vale a pena viver e que encontrou o Amor $\left({ }^{58}\right)$. No contexto das intenções ideológico-culturais do tempo - o livro tem na portada um texto "humanista" e "espiritualista" de Salazar $\left({ }^{59}\right)$ - o compilador, que não foi (antes pelo contrário) um "escritor do regime", não deixou de com ele se encontrar na intenção de reproduzir, divulgando poesias "acessíveis e agradáveis" para o grande público, uma concepção idealista da literatura e a noção, muitocara ao pensamento tradicionalista, de que Portugal era uma "Pátria de Poetas", entre os quais Antero era um dos maiores $\left({ }^{60}\right)$.

E como é que Antero foi ensinado na Escola? É difícil sabê-lo, porque só dispomos para isso de uma única fonte segura - os programas. Fora disso, apenas existem os manuais. Mas, se as "selectas literárias" do $3^{\circ}, 4^{\circ}$ e $5^{\circ}$ anos do "curso geral dos liceus" (equivalentes, grosso modo, aos actuais $7^{\circ}, 8^{\circ}$ e $9^{\circ}$ anos) eram frequentemente ou obrigatoriamente usadas na cadeira de Português, já o mesmo não sucedia, no "curso complementar", com os manuais de "História da Literatura" para os $6^{\circ} \mathrm{e} 7^{\circ}$ anos (hoje sensivelmente correspondentes ao $10^{\circ}$ e $11^{\circ}$ anos), dado que não se utilizava um "livro único", tendo-se usado ao longo do tempo e ao mesmo tempo vários compêndios,

$\left({ }^{57}\right)$ Portugal. Breviário, pp. 351-352.

$\left.{ }^{58}\right)$ Poesia de Ontem e de Hoje para o nosso Povo ler, "Colecção Educativa". Plano de Educação Popular, Lisboa s.d. [1957].

$\left({ }^{59}\right)$ O texto de Salazar que se encontra no início do livro - assim como se depara em todas as obras desta colecção um outro qualquer excerto da sua autoria, adequado aos diversos conteúdos dos vários livros, como que a marcar a sua doutrina orientadora - é o seguinte: "Eu não tenho dúvidas de que o mundo se transforma, sob alguns aspectos, aos nossos olhos, e também não as tenho de que nesse mundo, em que tudo se modifica, o que menos muda é o próprio homem. E isso quer dizer que, passada a tormenta, é outra vez do Espírito e dos seus valores que os Povos esperam a cura das feridas e o estabelecimento das condições da sua vida pacífica".

$\left.{ }^{(60}\right)$ Cfr. ob. cit., texto introdutório da autoria de Régio, "Uma Palavra". 
quando não se estudava pelos apontamentos tirados na aula. $O$ ensino dependia, pois, em grande parte, do professor e da sua orientação.

De qualquer modo, os programas e as referidas "selectas" dão-nos algumas indicações significativas. Quanto ao ensino do "curso geral", não há indicações sobre Antero nos programas do Estado Novo, que foram tendo várias versões. Mas, nas "selectas literárias" é, na verdade, comum encontrarmos alguns dos seus mais conhecidos sonetos de sentido religioso. Os sonetos "À Virgem Santíssima" e "Na Mão de Deus", e outros de sentido espiritualista, são, obviamente, os mais vulgares $\left({ }^{61}\right)$.

Quanto aos programas do "curso complementar", tem interesse captar o sentido da orientação de ensino. Nos programas de 1936 e de $1948\left({ }^{62}\right)$, este que se prolongou pelas décadas seguintes, é curta a referência a Antero: "a dissidência de Coimbra e as conferências do Casino. Antero de Quental". Mas é mais explícito o texto de orientação para os professores, que consta nas "Observações" ao programa.

Tendo a cadeira de Português desse ciclo como um dos objectivos "arraigar no espírito e no coração dos alunos sentimentos elevados de civismo e de amor da Pátria" - como se diz no programa de 48 , ideia que curiosamente era mais atenuada no de 36 - o ensino de Antero de Quental mereceu cuidados especiais por parte dos legisladores. No programa de 1936 pode ler-se este texto esclarecedor: "Quanto à personalidade de Antero de Quental, não é ela para ser estudada neste curso; limite-se a leitura a alguns sonetos e comentário a uma ideia, embora imprecisa, da tormentosa vida mental do poeta e do significado da sua arte, procurando interessar algum aluno por estudos mais completos a fazer ulteriormente" $\left({ }^{63}\right)$. No programa de 48 parecem ser ainda maiores, curiosamente, os cuidados do Ministério da Educação,

( $\left.{ }^{61}\right)$ Vide, por ex., Bernardo Gonçalves Neto e Adriano Nunes de Almeida, Língua Portuguesa. Selecta Literária para $04^{\circ}$ e $5^{\circ}$ ano, Porto, Livraria Aviz, s.d., pp. 201-203. Vide também as várias edições da Selecta Literária, de José Pereira Tavares, "aprovada oficialmente" nos anos 30, 40 e 50, onde se seleccionam várias poesias de cunho espiritualista.

${ }^{(62}$ Cfr. Ensino Liceal. Reforma dos estudos e respectivos programas. Decreto-lei $n^{\circ} 27.084$ e decreto $n^{\circ} 27.085$ de 14 de Outubro de 1936..., $9^{\circ}$ edição, Lisboa, Imprensa Nacional,1946, e Programas das disciplinas do Ensino Liceal. Decreto n. 37.112 de 22 de Outubro de 1948, Lisboa, Imprensa Nacional, 1948. Veja-se particularmente a parte referente à disciplina de Português.

$\left({ }^{63}\right)$ Ed. do Programa de 1936 cit., p. 136. 
responsável oficial pelo ensino: "O drama espiritual de Antero dificilmente poderá ter ressonância condigna em rapazes de limitada experiência afectiva, intelectual e artística, como é de supor nos 16 anos dos finalistas liceais. Limite-se o professor a acompanhar a leitura de sonetos, escolhidos e comentados um por um, que dêem aos alunos ideia apreciável das ansiedades de um espírito sincero e nobre, rico de finas sensibilidades, enamorado de ideias generosas de justiça e humanidade, inclinado todavia à mística especulativa, e parecendo eternamente desesperado de encontrar o farol que procurava para lhe iluminar as trevas que lhe barravam os caminhos" $\left({ }^{64}\right)$.

Como se vê, num período já de fechamento do regime, após a frustrada abertura do pós-guerra, parecem aumentar as preocupações perante uma grande figura das letras nacionais, mas que era passível de gerar "alguns perigos" no seio da juventude. As preocupações são maiores do que em 36, ano fundamental para a institucionalização do Estado Novo e em que o Ministério da Instrução Pública se passa a denominar Ministério da Educação Nacional, adoptando medidas pedagógicas de ressonância fascista.

\section{O Centenário de Antero - encontro de várias leituras}

Antero, como se anotou, não foi transportado para o Panteão Nacional no fim do século, como sucedeu ao seu amigo João de Deus, em 1896, por altura da sua morte, nem mais tarde quando foi inaugurado o Panteão em Santa Engrácia. No entanto, naquela época comemoracionista, mercê das concepções demoliberais e positivistas, não deixou de se publicar, em 1896, um In Memoriam, em que os seus amigos e admiradores escreveram textos de homenagem. Alberto Sampaio, Vasconcelos de Abreu, Adolfo Coelho, Oliveira Martins, Magalhães Lima, Anselmo de Andrade, Carolina Michaëlis, Guerra Junqueiro, Eça de Queirós, João de Deus e tantos outros aí publicaram os seus artigos, que se distribuem entre a memória e as primeiras tentativas de interpretação científica da personalidade e da obra de Antero $\left({ }^{65}\right)$.

Logo em 1901, já também o dissemos, os estudantes açorianos

${ }^{(64)}$ Ed. do Programa de 1948 cit., p. 36.

${ }^{(65)}$ Antero de Quental. In Memoriam, Porto, Mathieu Lugan, 1896. 
movimentaram-se para homenagear o poeta, a que deram o seu apoio expresso figuras importantes da intelectualidade e dos meios universitários de Coimbra. Aliás, nesta cidade, onde estudou e onde foi célebre pelas atitudes de revolta contra os poderes universitários instituídos, foi-lhe consagrada uma rua pela Câmara Municipal, logo em $1903\left({ }^{66}\right)$. Enfim, Antero tornava-se poucos anos depois da sua morte uma "figura nacional".

Mas, acima de tudo o que queremos analisar com um pouco mais de atençãoé o que se passou em 1942, em pleno Estado Novo, data em que - como por várias vezes se disse - se celebrou o primeiro centenário do seu nascimento. Antes, porém, de o fazermos, deveremos recordar que o ano de 40 é marcado por um centenário nacionalista, de importância ímpar no reforço da ideologia do regime - o duplo centenário da Fundação e da Restauração da Nacionalidade. Como seria então "interpretado" dois anos depois o centenário de Antero?

O que se verifica é o encontro de todas as tendências e de todas as ideologias interpretativas, ainda que o regime procurasse, obviamente, dominar esse movimento comemorativo, conferindo-lhe grande importância. Basta ler os jornais do tempo para se encontrar um noticiário variado, por vezes acompanhado de alguns comentários esclarecedores. Vejamos alguns exemplos $\left({ }^{67}\right)$ :

Em Lisboa houve uma exposição sobre Antero no Museu João de Deus. Na Casa dos Açores, Vitorino Nemésio proferiu uma conferência, e a direcção da Casa depôs um ramo de flores na estátua de Antero que se encontrava no átrio da Câmara Municipal. No Liceu Filipa de Lencastre houve uma sessão comemorativa. Mas, acima de tudo, o que os jornais noticiaram, quanto à capital, foi a "sessão solene" realizada na Academia das Ciências. Presidida pelo Ministro da Educação, Mário de Figueiredo, teve - como era tradicional dizer-se - "numerosa e selecta assistência", tendo nela pro-

${ }^{(66)}$ Cfr. J. Pinto Loureiro, Toponímia de Coimbra, t. II, Coimbra, Edição da Câmara Municipal, 1960, p. 93.

$\left({ }^{67}\right)$ As notícias que se seguem foram respigadas nos jornais de Abril de 1942 (Antero nascera em Ponta Delgada em 18 de Abril de 1842), nomeadamente nos periódicos que tinham, por assim dizer, um certo carácter oficioso, ou seja, oDiário da Manhã e o Diário de Notícias. 
ferido uma conferência sobre Antero o seu presidente, Júlio Dan$\operatorname{tas}\left({ }^{68}\right)$.

No Porto - onde as comemorações parece terem tido um cunho menos oficial - no Ateneu Comercial proferiram conferências Casais Monteiro, Manuel Mendes, o Padre Alves Correia e Agostinho da Silva, enquanto no Palácio de Cristal, promovida pela associação "Estudos Portugueses", Santana Dionísio falava sobre Antero.

Em Coimbra a Academia promoveu uma jornada comemorativa, a que vamos prestar uma especial atenção, enquanto em outras cidades se levavam também a cabo cerimónias de homenagem. Em Ponta Delgada, como não podia deixar de ser, houve significativas "Festas Centenárias", passando a chamar-se ao Jardim do Colégio (por ali existir o Colégio dos Jesuítas) Jardim Antero de Quental, e tendo sido colocado no local um busto do poeta, da autoria de Canto da Maia. Note-se, como curiosidade representativa, porque supõe a ideia de que o poeta estáligado à Natureza, que os jardins foram os locais escolhidos para erguer estátuas a Antero. Assim aconteceu em Lisboa, onde foi colocada, no Jardim da Estrela, em 1948, sendo a obra da autoria de Barata Feio $\left({ }^{69}\right)$, e em Coimbra, no Parque da Cidade, onde a Câmara Municipal, em 1958, mandou instalar um busto executado por Diogo de Macedo, oferecida pelo município lisboeta $\left({ }^{70}\right)$. Os artistas no período salazarista não deixaram, pois, de contemplar Antero de Quental, através das suas obras de cunho mais livre ou oficial. Está neste caso, embora se trate de um conjunto onde Antero também está presente, e não de uma obra expressamente sobre ele, o convencional painel que evoca a história e a cultura de Portugal, da autoria de Severo Portela, existente no átrio da Faculdade de Letras de Coimbra, de construção do Estado Novo, inaugurada em 1951. Ali, entre outras

${ }^{\left({ }^{68}\right)}$ Vide Júlio Dantas, Discurso proferido na Sessão Comemorativa do $1 .^{\circ}$ Centenário de Antero de Quental, em 18 de Abril de 1942, Separata do Boletim da Academia das Ciências de Lisboa, vol. XIV, Abril de 1942.

${ }^{(69}$ ) Cfr. R. Laborde Ferreira e V. M. Lopes Vieira, Estatuária de Lisboa, Lisboa, 1985, p. 130.

$\left({ }^{70}\right)$ Cfr. Arquivo Coimbrão, vol. XVII, Coimbra, 1959, p. 1 ss. 
figuras históricas e literárias, encontramos, na verdade, Antero de Quental ( $\left.{ }^{1}\right)$.

Voltando aos actos comemorativos realizados no país, pudemos ainda verificar que no Liceu Bocage, de Setúbal, houve também uma jornada de homenagem a Antero, enquanto em Vila do Conde a Câmara Municipal mandou descerrar uma lápide na casa onde o poeta viveu. Mas não foi só em Portugal que se realizaram comemorações. 0 exemplo do Brasil é sintomático da junção nessas cerimónias - junção aparentemente contraditória se analisada de forma simplista - do cunho oficial e da intervenção de personalidades que nada tinham a ver com o regime ou que eram mesmo contra ele. No Rio de Janeiro a sessão foi promovida pelo Departamento de Imprensa e Propaganda (D.I.P.), correspondente ao nosso S.P.N./S.N.I. Nessa sessão solene, realizada na Assembleia Brasileira de Imprensa, presidida pelo Embaixador Martinho Nobre de Melo, figura importantíssima do Salazarismo, que proferiu - no dizer dos jornais do tempo - "um notável discurso", falaram o poeta e académico brasileiro Manuel Bandeira e Jaime Cortesão, para além de ter havido um recital pela declamadora Margarida Lopes de Almeida.

Mas os jornais, cujo noticiário seguimos de perto, não se limitam a um mero registo de acontecimentos, aos quais acrescentamos - por nos parecer significativa - a palestra proferida na Rádio Renascença pelo Padre Moreira das Neves sobre o tema "Antero e as crianças". Também eles tecem comentários bem reveladores das tendências interpretativas em relação ao poeta, bem como inserem artigos de fundo sobre Antero de Quental.

Por exemplo, saliente-se que foi no Diário de Notícias que se publicou, sob a forma de artigo, o estudo de Luiz Teixeira sobre a vida de Antero, depois publicado em opúsculo $\left({ }^{72}\right)$. Todavia, o mais interessante

(71) O reitor Maximino Correia, que era também o presidente da Comissão Administrativa das Obras da Cidade Universitária de Coimbra, terá chegado a sugerir que na nova cidade universitária fosse evocado, numa obra plástica, o célebre episódio romântico referido por Eça de Queirós nas Notas Contemporâneas, em que Antero se encontrava a recitar, nas escadarias da Sé Nova, numa noite de luar, tendo à volta um grupo de estudantes ("Sugestões de Lembranças que a Cidade Universitária deve perpetuar em obras de arte, enviadas a S. Ex². o Ministro", Ao serviço da Universidade de Coimbra, 1939-1960, Coimbra, 1963, p. 161).

$\left({ }^{72}\right)$ "No Centenário do Poeta. Alguns factos da sua vida", Diário de Notícias, 18.4.1942. 
detecta-se na leitura dos periódicos intimamente ligados à área católica e ao regime, como são os casos do Novidades e de $A$ Voz.

Num artigo de fundo de $A$ Voz, "A Lição de Antero", assinado por Deniz da Luz $\left({ }^{3}\right)$, surgem no fundo duas lições, que se podem sintetizar em dois passos fundamentais do discurso. Vejamos a primeira, que se radica na tradição interpretativa de Sardinha: "O moço revolucionário demoliu muita coisa respeitável, a frente de uma impetuosa corrente juvenil, encadeada por falsos esplendores. Não falta, porem, quem nele descortine, por entre os erros e excessos que cometeu uma autêntica mentalidade de precursor da Contra-Revolução, um inimigo das corrosivas doutrinas liberais, como se propunham na época, e um defensor dos interesses da nação, pessimamente servida". O segundo passo reflecte melhor a ideia da luta entre o "mal" e o "bem" em Antero, de onde se extrai um outro ensinamento fundamental: "Depois a lição de Antero é preciosa. A sua vida ensina-nos aonde leva $\mathrm{o}$ abandono da fé, a falta de directrizes espirituais e o pessimismo. E a sua obra traduz uma ânsia de realização do bem, como o entendia; e afirma a constante inquietude do seu espírito. Antero não era cristão, na integridade da fé sequer, mas a 'voz interior' que nele afirmava o bem parecia ser cristã".

No jornal católico Novidades $\left({ }^{74}\right)$ aparecem, nos artigos do centenário, sobretudo sugestões acerca da sua espiritualidade e o repúdio dos seus erros. Daí que na folha "Letras e Artes", que era dirigida por Moreira das Neves, se encontre uma imagem disso bem sintomática. Trata-se de uma fotografia que foca um rochedo abrupto sobre o mar e o sol poente, com a seguinte legenda: "Toda a vida de Antero foi um mar misterioso, sob a luz do sol poente e com a cruz sobre um rochedo". A questão da morte, e da vida, de Antero de Quental preocupou sobretudo os católicos, como já vimos. Eles não podiam, apesar de tudo, esquecer os seus "desvarios", embora o considerassem, como era comum, um dos "maiores poetas de todos os tempos". Por isso o editorial concluía: "Apreciemo-lo como poeta e pensador; mas deploremo-lo como homem-pelo muito que sofreu e pelo mal que fez, no campo das ideias, à sociedade portuguesa". Antero é uma grande figura nacional, mas é também o "pecador", o corruptor social.

\footnotetext{
( $\left.{ }^{73}\right)$ A Voz, 18.4.1942.

$\left({ }^{74}\right)$ Novidades, 18.4.1942.
} 
Vejamos agora o caso sintomático da homenagem a Antero que lhe foi prestada pela Academia de Coimbra.

Era presidente da Associação Académica, em período de comissões administrativas nomeadas pelo governo, e da sua confiança, 0 estudante de Direito João de Matos Antunes Varela, que virá a ser uma figura fundamental do regime, ocupando durante quase treze anos, praticamente sucessivos, o cargo de Ministro da Justiça (1954-1967). Uma direcção deste tipo levaria a efeito, naturalmente, uma celebração integrada no "sistema", embora abrindo-se - como era usual do próprio "sistema" - a algumas personalidades que o não representavam.

O jornal Via Latina, órgão da A.A.C., espelha e corporiza este tipo de homenagem centenária de modo claro $\left({ }^{75}\right)$. É autor do editorial uma figura da intelectualidade oficial, o presidente da Academia das Ciências, Júlio Dantas. Escreve ainda um artigo, entre outros, Ruy Galvão de Carvalho, conhecido anterianista de ideologia "tradicional", e publica uma poesia inédita o conhecido poeta católico, nacionalista e ruralista, figura do regime e do sector académico "integralista", António Correia de Oliveira. O seu poema tem o significativo título "Antero e o Soneto à Virgem".

A descrição das "festas comemorativas", a presença de certas personalidades e o tom dos seus discursos ou conferências são reveladores do espírito centenarista que caracterizou esta homenagem a Antero.

No primeiro dia, 16 de Abril de 1942, foi descerrada uma lápide nos Palácios Confusos, numa das casas em que morou Antero enquanto

$\left({ }^{75}\right)$ Vide sobre o que adiante se refere Via Latina, Ano II, $n .^{\circ} 10,30.4 .1942$. Tratase de um número especial, integralmente dedicado - como se diz no Editorial - às "Comemorações do $1 .^{\circ}$ Centenário de Antero de Quental, realizadas pela Academia de Coimbra". Vimos também outros jornais da cidade, onde encontrámos idêntica informação sobre o que se passou nas comemorações académicas. O Diário de Coimbra, muito especialmente, segue a par e passo o sucedido. Chamou-nos a atenção of acto de nele vir incluído um artigo, assinado por Adriano Proença, intitulado "Antero 'O Santo"' (D. C., 19.4.1942). No Correio de Coimbra, jornal católico, para além de uma breve notícia das comemorações, surgem vários testemunhos de autores católicos sobre Antero: Joaquim Manso, Moreira das Neves, Carlos Eugénio Paço d'Arcos e Gonçalves Cerejeira (C. C., 25.4.1942). Na revista Estudos, dos estudantes católicos do C. A. D. C. (Centro Académico de Democracia Cristã), pouca atenção se presta ao centenário de Antero. Apenas encontrámos nela um artigo, da autoria do Dr. Alberto Rêgo, intitulado "Antero e Beethoven" (revista cit., Abril de 1942). 
estudante $\left({ }^{76}\right)$. Falaram nessa cerimónia, que terminou com o Hino Nacional, entoado pelo Orfeon Académico, Manuel Dias da Fonseca, representante da direç̧ão da Associação Académica, o Dr. Abel Mendonça, pela Câmara Municipal, e o Doutor Maximino Correia, Vice-Reitor e Reitor interino da Universidade.

Detenhamo-nos em alguns passos significativos destes discursos, onde é evidente o presentismo da leitura de Antero:

O estudante Dias da Fonseca detectou, como era vulgar, as "qualidades" eos "defeitos" de Antero. Não vamos registarem pormenor as suas palavras, mas não poderemos deixar de transcrever o último passo do discurso, bem revelador da tendência dominante da Academia de então: "A Academia de Coimbra contudo não pode apontar Antero como exemplo, modelo e guia da juventude portuguesa; são hoje diferentes os quadros da vida, é outra a directriz que norteia a mocidade: a fé tradicional, o respeito pelos antepassados da nossa história, a manutenção das instituições e costumes do povo português, são factores da vida nacional que temos, não só que conservar, mas, mais do que isso, que estimular e aumentar. A experiência liberal e a tentativa de igualdade, não frutificaram entre nós; os seus resultados foram, antes, desastrosos; consequentemente temos que atender, sobretudo, à tradição portuguesa. Em vez do internacionalismo, a juventude quer a sua pátria cada vez mais alta; por ela se baterá até à morte, se necessário for. A Pátria enche os corações da mocidade de hoje, que, acima dela, só vê Deus. A juventude precisa de um ideal forte, que a oriente; doutro modo debater-se-á angustiosamente, chegando, por vezes, a aniquilar a própria vida, tal como aconteceu a Antero, que, por isso, não pode ser apontado como guia da mocidade". Assim, a saudação a Antero não ia para o "político e revolucionário", mas sim para o "grande Poeta e Filósofo da Literatura Portuguesa".

Pouco mais restará analisar nos discursos desta primeira sessão comemorativa. Quando um estudante emite esta profissão de fé num idealismo voluntarista de tipo nacionalista, logo nos situamos no espírito da corrente dominante que marcou o centenário de Coimbra. $\mathrm{O}$ testemunho de Abel Mendonça, um intelectual tradicionalista, ia

$\left.{ }^{(76}\right)$ É curiosa a observação do Diário de Coimbra, proferida em tom de crítica, relativamente à assistência a esta cerimónia: "Muitos estudantes. Poucos lentes..." (D. C., 18.4.1942, "Festejando uma data" por Carminé Nobre). 
necessariamente em sentido idêntico, se bem que o seu discurso se compraza sobretudo na interpretação directa de Antero e não tanto em observações presentistas. No entanto, Antero era também para ele o homem "enraizado nas virtudes ancestrais do Portugal católico, o Portugal eterno" que se deixou seduzir pela Razão - "A desgraça indizível de Antero foi ter-se acolhido à sombra da Colina Sagrada $\left({ }^{77}\right)$ sob o signo de Kant". A "lição de Antero" é que não é possível a Razão sem Deus. "A harmonia e o equilíbrio perfeito da nossa existência - escrevia o Dr. Abel Mendonça - corre um perigo mortal se perde contacto com a verdade eterna, que por grande bênção de Deus, afeiçoou a alma lusíada".

$\mathrm{O}$ discurso de Maximino Correia é também bem significativo. $\mathrm{O}$ Vice-Reitor seleccionou, no contexto duma visão tradicional do país e de Coimbra, a ideia queirosiana da "santidade" de Antero. Portugal é um oásis num mundo conturbado e por isso pode celebrar o símbolo que constituiu Antero de Quental. Eis um passo da alocução do Reitor em exercício: "E é neste mundo, abalado até aos seus fundamentos sociais, dilacerado e revolvido até às entranhas, no mar, na terra e no céu, que Portugal, por mercê de Deus e de quem o governa, amargurado por não lhe serem indiferentes tantos horrores, mas de alma tranquila e confiante, se levanta para celebrar o primado do espírito, o génio da Ideia, os sentimentos da Belezae da Bondade, consubstanciados no Homem que foi Antero de Quental". Assim, ficava para trás o "socialista arrebatado", o "iberista", o "irreverente" da Sociedade do Raioe homenageava-se "ohomem coerente e justo, corajoso e honrado, leal e bom...", numa palavra "o Santo Antero".

É esta ideia das virtudes de Antero que foi, de resto, retomada pelo Presidente da Associação Académica, ao apresentar no Salão Nobre a conferência do seu colega açoriano, finalista da Faculdade de Letras, Manuel de Sousa Oliveira, que proferiu uma conferência sobre o poeta, na noite do mesmo dia da homenagem nos Palácios Confusos. Aqui é

$\left({ }^{77}\right)$ "Colina Sagrada" é o nome que literariamente se dá a Coimbra ou à zona "alta" da cidade, onde se instalou desde o século XVI a Universidade. Foi este, aliás, o título que Manuel Ribeiro deu ao romance que publicou em 1925 (A Colina Sagrada, Lisboa, Guimarães e C.: Editores, 1925). 
sobretudo o "espírito científico" que vem ao de cimo, numa análise que procura ser objectiva $\left({ }^{78}\right)$.

É também o "espírito científico", embora marcado por uma concepção católica, que caracteriza a conferência de Álvaro Júlio da Costa Pimpão, realizada no Salão Nobre da Faculdade de Letras $\left({ }^{79}\right)$, onde aquele era professor, no segundo dia dos festejos comemorativos, 17 de Abril, à qual se seguiu a declamação de alguns poemas de Antero. Costa Pimpão analisa a questão fundamental da cronologia dos sonetos, não para afirmar, como o fez a corrente católica oficial, o cristianismo de Antero, mas sim para o negar, como curiosamente o fez, com outros intuitos, a corrente laicista, de que Sílvio Lima foi exemplo. "Negando a fé ao escólio do filosófo, - conclui Costa Pimpão, homem de formação católica e tradicionalista - eu não tive a intenção de desrespeitar a sua memória nesta noite consagrada ao Poeta. Pelo contrário: foi o respeito do poeta - e da sua dor - que me levou a sugerir (...) que a sua grandeza está justamente em ter negado o filosofo; em ter ousado afirmar, contra todas as filosofias, a existência de um conflito insanável para toda a alma portadora de Cristo (e é-se portador de Cristo pelo baptismo...) que teima em procurar fora d'Ele a solução do seu próprio destino. Na dolorosa, na trágica confissão desta verdade, se resume, a meu ver, a mensagem do Poeta".

$O$ terceiro e último dia do centenário foi o dia de gala - em 18 de Abril realizou-se a "sessão solene" na Sala dos Capelos, onde Antero tomara posição de luta contra o então reitor Basílio Alberto de Sousa Pinto, símbolo do conservadorismo universitário. Aliás, tal facto justificou um discurso de concepção "paternalista", ou "maternalista", da Universidade por parte de Maximino Correia, que encerrou a sessão - a Universidade como "Mãe magnânima que esquece facilmente as travessuras dos filhos", isto é, as "irreverências de Antero".

Não conhecemos o discurso de abertura de Antunes Varela, que falou para um auditório em que estavam presentes as autoridades e 0 presidente da Assembleia Nacional, José Alberto dos Reis, bem como

${ }^{(78)}$ Manuel de Sousa Oliveira defendeu uma dissertação de licenciatura, na Faculdade de Letras de Coimbra, em Histórico-Filosóficas, sobre Antero: Antero de QuentaL Príncipios filosóficos e concep̧̧ões religiosas, Coimbra, 1942.

$\left({ }^{79}\right)$ A conferência foi também publicada na revista Biblos, vol. XVIII, t. I. 
professores e estudantes, "todos de capa e batina". Apenas conhecemos, pela Via Latina, que estamos a analisar, uma breve descrição, que tem como ponto saliente o seguinte passo: "Referiu-se a Salazar, evocando um verso de Fernando Pessoa para exaltar Portugal, e terminou o.seu discurso fazendo uma evocação a Antero". Mas os convidados a proferir discursos nesta sessão não se identificavam com o regime - eram ambos professores universitários especialistas de história da cultura portuguesa, Hernâni Cidade, da Faculdade de Letras de Lisboa, e Joaquim de Carvalho, da Faculdade de Letras de Coimbra.

Ambos se terão desviado da polémica, mas revelaram as imagens fundamentais de uma interpretação "objectiva" - ainda que intencionalmente em discurso leve e informal - mas "laica", que fugia às leituras tradicionalistas, normalmente expendidas neste centenário de Coimbra. Hernâni Cidade apresenta Antero como o "espírito da cultura", como o poeta que (para utilizar uma ideia de Rimbaud) rouba o "fogo sagrado", para assim concluir: "Tanto importa que no-lo traga dos abismos inferiores, através da treva subterrânea, como do céu, através dos espaços constelados". Quanto a Joaquim de Carvalho, apresenta o Antero multiforme, quase desdobrado em vários perfis ao longo do tempo (o "homem novo", o "desesperado", o "sages") mas sobretudo o Antero "homem" e que "só com os homens aprendera alguma coisa", o Antero que "conheceu, como raros escritores portugueses, o homem e a realidade humana". "Filosofo da liberdade" - eis a imagem-base que procura apresentar aos estudantes, a quem expressamente se dirige no final do discurso.

Duas imagens "laicas" - a de uma cultura amoral e a de um humanismo social. Curiosamente a celebração de Coimbra terminou com estas leituras relativamente "heterodoxas" de Antero. Na verdade, este Centenário de 1942, embora marcado pelo "regime", teve "fugas" à linha que ele lhe marcou. Em Coimbra e noutros lugares. A Cidadela do Estado Novo teve as suas vulnerabilidades ou criou-as, pois elas não deixavam de ser importantes para a sua imagem, desde que não ofendessem essencialmente a solidez das suas muralhas.

\section{Conclusão}

No centenário de Coimbra o estudante Antunes Varela, ao apresentar a conferência do seu colega Sousa Oliveira, condenava - as palavras 
são suas - "a atitude da apresentação dum Antero construído ao sabor da ideologia, do parti-pris de cada um, com o forçar da vida do Homem e dos textos do autor à conformação biotipológica que se lhe traçou e à ideologia que se lhe atribuiu". Este "espírito científico" não terá afastado por certo o presidente da Associação Académica de uma leitura ideológica do centenário cuja organização liderou. Na verdade, como no início dissemos, história e ideologia têm relações tão íntimas que não é possível nunca separá-las de todo.

E isso é sobretudo evidente no caso de Antero de Quental, cuja "contemporaneidade da sua obra" é constantemente afirmada. Disse dela Ruy Galvão de Carvalho no centenário de $42\left({ }^{80}\right)$ e continuaram a dizê-lo diversos leitores do poeta-filósofo. O problema porém - e é isso que frequentemente se esquece - é que o escritor, para além da "actualidade" da sua arte e do seu pensamento, tem também a sua "história". Sem se ter consciência profunda dessa realidade, não é possível analisá-lo "objectivamente", mesmo que se saiba - e há que encarar isso sem dramatismo - que essa "objectividade" nunca é isenta de ideologia.

Analisámos, nas diversas cambiantes, as leituras "integralistas" de Antero de Quental. Obviamente que poderíamos ter feito o mesmo para as leituras "republicanas" ou "socialistas". Sem nos considerarmos especialistas de Antero, procurámos dar a conhecer melhor o fenómeno complexo da recepção do poeta. Seguimos sugestões já traçadas e uma pista muito ampla - no âmbito da história da História - que vimos a trilhar há já vários anos, num caminho infindável mas sempre atraente.

${ }^{(80)}$ "Antero vivo", in Via Latina cit. 